\title{
Influence of different sources of topographic data on flood mapping: urban area São Vendelino municipality, southern Brazil
}

\section{Influência de diferentes fontes de dados topográficos no mapeamento de inundação: área urbana do município de São Vendelino, sul do Brasil}

\author{
Fernando Campo Zambrano ${ }^{1}$ (D), Masato Kobiyama ${ }^{1}$, Marco Alésio Figueiredo Pereira ${ }^{2}$, Gean Paulo Michel ${ }^{1}$ \& \\ Fernando Mainardi Fan ${ }^{1}$ \\ ${ }^{1}$ Instituto de Pesquisas Hidráulicas, Universidade Federal do Rio Grande do Sul, Porto Alegre, RS, Brasil \\ ${ }^{2}$ Universidade Feevale, Novo Hamburgo, RS, Brasil \\ E-mails: fernando.zambrano@ufrgs.br (FCZ), masato.kobiyama@ufrgs.br (MK), marco@feevale.br (MAFP), gean.michel@ufrgs.br (GPM), \\ fernando.fan@ufrgs.br (FMF)
}

\begin{abstract}
Generally, the base for any flood mapping is the topography information whose resolution determines the map accuracy. Furthermore, river bathymetry in detail and the type of used model are also relevant. Therefore, the objective of the present study was to evaluate the influence of different sources of topographic data on the flood mapping by using the CAESAR-Lisflood model and three Digital Elevation Model (DEM) configurations, among which two were freely available, and the other was generated with field survey (topography and bathymetry). First, the resolution and precision of each DEM were evaluated, from the comparison of different cross-sections, besides the variation of the wetted area and absolute value of the relative error in mean velocity as a function of depth. Subsequently, after elaborating flood maps with each DEM, the results were compared in terms of flood area, mean flood width and flow depth. It is observed that the more accurate resolution, the smaller the flood area becomes. The flood map elaborated with the DEM through field survey had the best fit to the observed area. However the relation between the topographic resolutions and flow-depths was not clear in obtained results.
\end{abstract}

Keywords: Topographical sources; DEM; CAESAR-Lisflood; Flood; Mapping.

\section{RESUMO}

Geralmente, a base para qualquer mapeamento de inundação é informação sobre topográfica cuja resolução determina a precisão do mapa. Além disso, a batimetria detalhada do rio e o tipo de modelo usado também são relevantes. Portanto, o objetivo do presente estudo foi avaliar a influência de diferentes fontes de dados topográficos no mapeamento de inundações utilizando o modelo CAESAR-Lisflood e três configurações de Modelo Digital de Terreno (MDT), dentro das quais, duas estão disponíveis gratuitamente e outra gerada com levantamento em campo (topografia e batimetria). Primeiramente, foram avaliadas a resolução e a precisão de cada MDT, a partir da comparação de diferentes seções transversais, além da variação da área molhada e do erro relativo da velocidade média em função da profundidade. Posteriormente, após a elaboração dos mapas de inundação com cada MDT, os resultados foram comparados em termos de área inundada, largura média de inundação e profundidade de fluxo. Observa-se que, quanto mais precisa a resolução, menor a área de inundação. O mapa de inundação elaborado com o MDT por meio de levantamento em campo teve o melhor ajuste para a área observada. Entretanto, a relação entre a resolução topográfica e a profundidade do fluxo não foi bem clara nos resultados.

Palavras-chave: Fontes topográficas; MDT; CAESAR-Lisflood; Inundação; Mapeamento. 


\section{INTRODUCTION}

Hydrological disasters related to floods have been increasing considerably and causing serious socioeconomic and environmental damages including human losses in the world. According to data available in the Emergency Events Database (EM-DAT), flood disasters in 2016 accounted for $47.9 \%$ of total disasters and caused 77.9 million victims, $54.2 \%$ of all the human deaths and $38.2 \%$ of the total damages (Guha-Sapir et al., 2016).

In Brazil, the type of disaster that causes the largest number of deaths is flash flood with $58.2 \%$, followed by mass movements. In terms of flash floods, the southern region of Brazil represents the largest records, with 39\% (Universidade Federal de Santa Catarina, 2013).

Thus, the Brazilian government began to implement various measures for the flood disaster prevention. One of them is flood hazard mapping which provides information on the areas prone to this natural phenomenon and support land management as well as evacuation routing establishment in warning system. Based on the guidelines of the Brazilian National Policy on Protection and Civil Defense (PNPDEC) under Federal law 12.608/2012, and with the initiative of the Brazilian Geological Survey (CPRM), areas susceptible to flood were preliminarily elaborated for 881 municipalities that the National Plan for Risk Management and Natural Disasters Responses (PNGRRDN) considered very critical.

Currently, there are different methodologies and tools for flood mapping, including the hydrological and hydrodynamic modeling, as one of the most used to more accurately represent the spatial and temporal dynamics of flooding processes (Mai \& De Smedt, 2017; Pinho et al., 2015; Grimaldi et al., 2013; Monteiro \& Kobiyama, 2013; Paiva et al., 2011), and descriptive-qualitative approaches, whose use environmental information, such as soil type, relief shape, influence of vegetation cover, among others (Goerl et al., 2017; Pourali et al., 2016; Nobre et al., 2016; Degiorgis et al., 2012; Nobre et al., 2011) However, there are still uncertainties regarding the choice of the appropriate methodology and tool to be used to estimate the extent of the floods more accurately (Azizian, 2019). Generally, these uncertainties arise from several factors, for example, topographic information, hydrological monitoring data, model choice and/or model assumptions and parameters. However, the set of topographic data in relation to topographic maps or digital elevation models (DEM), has been one of the main factors that influence the accuracy of flood mapping (Jena et al., 2016; Teng et al., 2015; Saksena \& Merwade, 2015; Jung \& Merwade, 2012; Cook \& Merwade, 2009).

There are different ways to get the Digital Elevation model (DEMs) to be used in hydrodynamic studies. For example, spaceborne DEMs are largely available, such as Shuttle Radar Topography Mission - SRTM (Farr et al., 2007) and Advanced Spaceborne Thermal Emission and Reflection Radiometer - ASTER (Abrams et al., 2010). However, their resolutions are not always accurate, depending on the scale used in a work.

Yamazaki et al. (2012) discussed the usage of spaceborne DEMs for floodplains hydrodynamic modeling, and proposed an algorithm to remove in the DEM all the pits caused by vegetation canopies, sub-pixel sized structures, and random radar speckles. The accuracy of the adjust DEM derived from SRTM was validated using hydrodynamic simulations with the LISFLOOD-FP model (Bates et al., 2010) in a middle reach of the Amazon River. Testing spaceborne DEMs, Jung \& Jasinski (2015) proposed a called systematic approach to evaluate the relative vertical accuracy and spatial resolution of current and future satellite-based altimeters within the context of DEM requirements for $2 \mathrm{D}$ floodplain hydrodynamic model (LISFLOOD-ACC). Their results indicated a tradeoff relationship between DEM relative vertical error and grid-box size. Higher resolution models are the most sensitive to vertical accuracy. However the impact was reduced at coarser resolutions because of spatial averaging.

Another way to get a more detailed DEM is the use of a Light Detection and Ranging (LIDAR), from airborne surveys. Regarding airborne DEMs, Podhorányi et al. (2013) analyzed the effect of generated cross-section and the subsequent inundation areas from data obtained by the LIDAR method and constructed with different resolutions. The resulting cross-sections were confronted with the actual surveyed cross-sections, revealing adequate correlations.

Hsu et al. (2016) investigated the influence of DEM resolutions on 2-D flood inundation simulation in Sanyei drainage area of Tainan City (Taiwan). The authors started with a $1 \times 1 \mathrm{~m}$ LiDAR DEM and later used it as basis to aggregate several DEMs including: $5 \times 5 \mathrm{~m}, 10 \times 10 \mathrm{~m}, 20 \times 20 \mathrm{~m}, 40 \times 40 \mathrm{~m}$. Five flood inundation models were built based on the 5 DEMs with the same model setting. Results showed that the inundation area increased with coarser DEMs.

Indeed the usage of LIDAR-based DEMs is a very interesting approach. However it involves high costs and, according to Shen et al. (2015), the high resolution DEM data pose several disadvantages for floodplain modeling studies, for examples: (i) the data sets contain many redundant interpolation points; (ii) large numbers of calculations are required to work with data; and (iii) the data do not match the size of the computational mesh. Also, en though the LIDAR gives a detailed topographic data of land surface, it cannot generate the river channel geometry under water, which normally causes a significant error on estimating the extent of flood area (Werner, 2001; Bates et al., 2003; Yu \& Lane, 2006). On the other hands, Horritt \& Bates (2002) demonstrated that, without a detailed topographic survey in the floodplain, a 1D hydrodynamic model can sometimes perform in the same way compared to a $2 \mathrm{D}$ model for estimating the flood area. Most of 2D models work in a raster environment to represent the terrain's surface.

Vaze et al. (2010) analyzed the impact of using different DEMs on hydrologically important variables, as well as the loss of precision and reliability of results as a high-resolution DEM is used for a lower resolution DEM. The results clearly showed that the accuracy and resolution of the DEM influence the hydrological variables when using a DEM derived from the use of contour maps compared to a more detailed resolution map obtained by LiDAR techniques.

Saksena \& Merwade (2015) quantified the errors resulting from the properties of the DEM, such as resolution and precision in flood maps, showing that the elevations of the water surface and the flood area have a linear relationship with the accuracy of the DEM. Subsequently, they used this linear relationship between 
the extent of the flood and the accuracy of the DEM to create an approach for the development of more accurate flood maps, modeling the spatial distribution of the errors of the DEM's of less precise and thicker resolution. The results show that the accuracy of the flood maps can be significantly improved by modeling the spatial distribution of the DEM errors.

In this sense, Werner (2001); Haile \& Rientjes (2005); Horritt et al. (2006) also analyzed the impacts of DEM resolution on the accuracy of flood areas and found that the use of coarser resolution DEMs for small scale topographic features normally decreases the accuracy of the hydraulic properties and flood extensions.

Thus, the resolution and the accuracy of the DEM have been broadly discussed in the literature, because many actions of preventive measures against flood disasters start from the selection of DEMs used as input data of computational models. Therefore, to better understand the impacts of different DEM's on flood hydrodynamics studies, the present study aims to assess the influence of various sources of topographic data on the performance of flood mapping by using computational modeling and field survey.

Here, available DEM, DEM created from topographic maps of contour, and a DEM created from field survey in the floodplain and the river channel were used for this assessment. The created maps were analyzed and compared in terms of the extent flood area, mean flood width, and discharge depth. Although some studies on this topic, i.e., the effects of DEM on flood mapping, have already existed, the present study sought to deepen this knowledge by demonstrating the uncertainties and subjectivity associated with these effects.

\section{MATERIAL AND METHODS}

The methodology of this research followed the following steps. i) Create the different topographic configurations from a data set of contour lines, soil survey, bathymetry and DEM's obtained by remote sensing; ii) map the flood by using the hydrodynamic model LISFLOOD-FP inserted in the CAESAR-Lisflood model; and iii) analyze the performance of the different topographic configurations, comparing the results of the simulation and the base map for the analyzed event.

\section{Study area}

The study area is the reach of the main river that runs through the urban area of the municipality of São Vendelino, with a length of $3.7 \mathrm{~km}$ and contribution area of $218.36 \mathrm{~km}^{2}$. This contribution area is composed of two sub-basins, Santa Clara and Forromeco river. Over the entire length of the study area, the average width and depth are $33 \mathrm{~m}$ and $6 \mathrm{~m}$, respectively (Figure 1). This reach is part of the Forromeco river basin (area of $288 \mathrm{~km}^{2}$ and perimeter of $85 \mathrm{~km}$ ), located in the Rio Grande do Sul state, Brazil. This basin lies on the municipalities of Farroupilha, Barão, Carlos Barbosa, São Vendelino, Alto Feliz and Bom Princípio. Its elevation varies from 85 to $788 \mathrm{~m}$ (Figure 1).
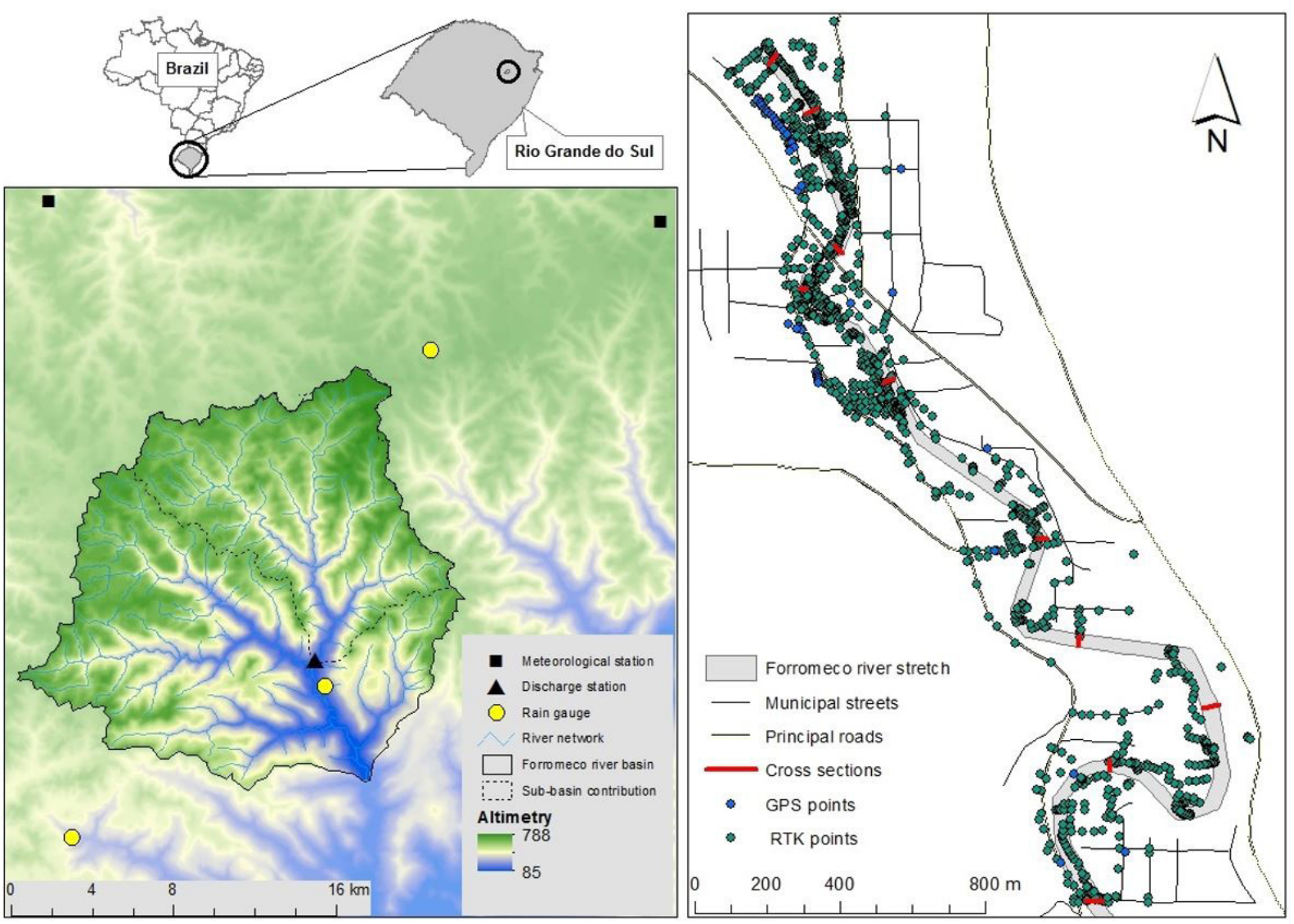

Figure 1. Location and altimetry of Forromeco river basin and the urban area of São Vendelino municipality. 
This reach is characterized by a relatively narrow floodplain and its meandering channel. Due to the absence of large flat areas, the urban area of the municipality of São Vendelino was established very close to the main river channel, thus leading to a frequent history of flood disasters (Figure 2). Based on information about the history of flood occurrences, the present study selected this reach to assess the different topographic configurations for the most significant event recorded in the municipality was using a two-dimensional hydrodynamic model.

\section{Topographic data}

A hydrodynamic model normally requires the DEM data that represent the actual geometric characteristics of the river channel and floodplain. With the DEM, elementary information can be extracted for the calculation of the topobatimetry and several geomorphic parameters of the channel and the floodplain. In the present study, three topographic data sets (DEM) were used.
The first product (DEM_1) was generated from an interpolation method developed specifically to create DEM's hydrologically correct (Hutchinson et al., 2011). For this, we used the data of contour lines with a $20 \mathrm{~m}$ contour interval, obtained from the Serra Gaucha Digital Cartographic Base (Hasenack \& Weber, 2007). This base was generated from the vectorization of 20 topographic maps on a scale 1:50,000 of the Directorate of Geographic Service (DGS) of the Brazilian Army and processed by the Geoprocessing laboratory of the Ecology Center of the Federal University of Rio Grande do Sul (UFRGS). These data cover the entire part of the Rio Grande do Sul state and are available for freely on the internet (Universidade Federal do Rio Grande do Sul, 2019).

The second configuration (DEM_2) is the DEM developed through the SRTM project, for a resolution of $30 \mathrm{~m}$ at the equator (Farr et al., 2007). However, considering the narrow width of the selected reach, the DEM was resampled for a smaller resolution. The resampling method was selected from the study on the topographic attributes sensitivity in the uncertainty of the DEM

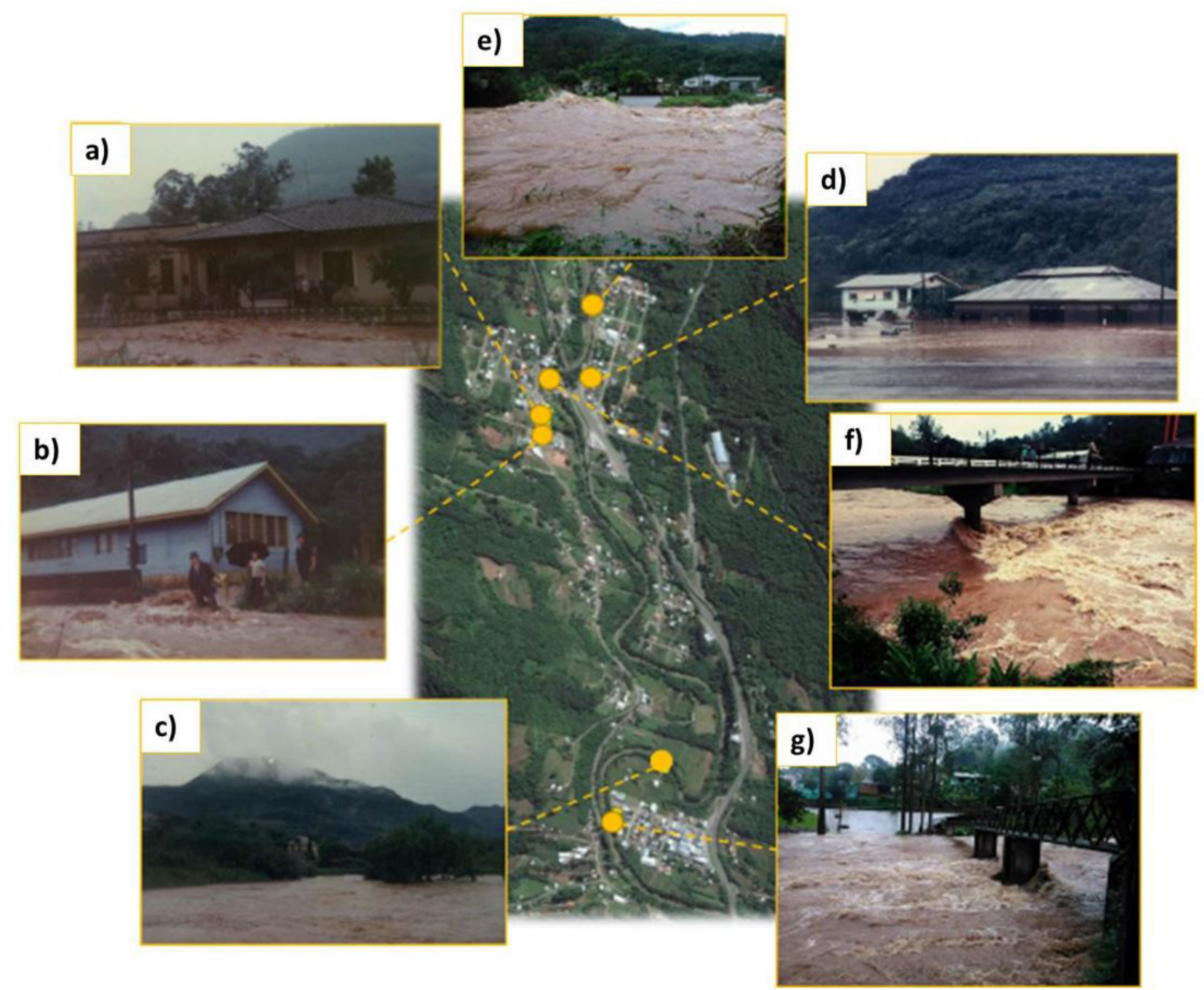

Figure 2. Flood events in the Forromeco river. Note that the photos (a), (b), (c) and (d) show the flood event of 1982 and the photos (e), (f) and (g) show the flood event of 2015. 
resolution by using three commonly used resampling methods proposed by Wu et al. (2008).

The third one (DEM_3) is topographic data obtained through the field survey with a differential GPS and a total station. At first, the investigation of the floods history in the basin was carried out with interviews to some local residents, and also based on information (photographs and technical reports) provided by the São Vendelino city hall. After that, the points of the affected area of the largest flood event which occurred in 1982 were established. The topographic survey was performed for the entire flood area from the quoted points, by using the Hiper v topcon equipment of the double frequency and processed in the MAGNET Tools 2.0 topography software. This equipment uses the real-time kinematic positioning technique (RTK) which is a high-precision system based on the use of navigation technologies with satellite signals, where a reference station provides real-time corrections of the instantaneous coordinates, thus improving the accuracy of the measurement points.

Subsequently, a topobatimetry survey of the river channel was carried out, in order to represent it better. In this case some geomorphic characteristics of the channel such as slope changes, river curvatures, accessibility at the site, etc. were considered. Thus, the measurement sections distributed throughout the channel were defined. The transversal profile of each section was determined by composing Geometric Leveling (GL).

Based on the initial DEM and the field survey detailed data, a new DEM of the flood area was constructed as a boundary condition for the hydrodynamic simulations. In this case, a linear interpolation of the measured sections was first performed through the geometry tool within the HEC-RAS 4.1 model (United States Army Corps of Engineers, 2010), in order to represent the entire channel to be simulated. In this way, together with the survey of the quoted points and tools of the ArcGis software, a new Raster was generated. Thus the new DEM can represent the very precise conditions of both the channel and the floodplain. Therefore, considering the narrow width of the selected section (approximately $33 \mathrm{~m}$ ); the final resolution (pixel) of the DEMs was $5 \mathrm{~m}$.

\section{Hydrological data}

The hydrological data necessary for the modeling were obtained with the Brazilian National Agency of Water (ANA) database which is available in HidroWeb hydrological information system (Agência Nacional de Águas, 2019). These data are series of rain and discharge. Figure 1 shows the location of the rain gauge, discharge and meteorological stations used in the present study. The discharge station is located in the outlet of the Forromeco river sub-basin (area of $116.74 \mathrm{~km}^{2}$ ) whose data were utilized for hydrological model calibration in the present study.

At first, the Thiessen method was used to create a single historical series of mean daily rainfall in the study basin. Afterwards, the daily rain was transformed into an hourly one through the relationships between rain of different durations based on the technique proposed by Back et al. (2012). This was analyzed and described by Zambrano et al. (2015).

The determination of the hyetograph for the hydrological simulations was due to the largest event recorded on July 28th,
1982. In addition, the present study took into account the result demonstrated by Monteiro \& Kobiyama (2014) where, the later the peak of the rainfall occurs, the higher the peak flow becomes, and consequently the larger the flood area. Therefore, the present study adopted the hyetograph peak at $75 \%$ of the total rainfall duration.

\section{Application of CAESAR-Lisflood}

The CAESAR-Lisflood (Coulthard et al., 2013) is a landscape evolution model that simulates the development of morphology from the propagation of surface runoff and sediment transport. This model works from a raster environment, evaluating the changes of elevations of each cell through erosion and deposition of fluvial and slope processes. The CAESAR-Lisflood was chosen considering that the final study would be an analysis of river evolution processes, from results of erosion and sediment transport due to extreme flood events. According to Skinner et al. (2018), a sensitivity analysis of a large number of parameters in this model showed that one of the most sensitive input parameters is the resolution of DEM.

This model integrates four different processes: hydrological, hydrodynamic, erosion and fluvial deposition, and slope processes. However, the present study used only the hydrological and hydrodynamic processes inserted in the CAESAR-Lisflood model.

For simulating the hydrological processes in the basin, the CAESAR-Lisflood model simplified the TOPMODEL developed by Beven \& Kirkby (1979). The TOPMODEL model in its original version is a semi-distributed model and uses the concept of variable source area which is important in determining the storage deficit.

The modification of the TOPMODEL which was inserted into the CAESAR-Lisflood allows the estimation of flow generation by the combination of surface and subsurface flow $Q_{t}$ in each cell.

$Q_{t}=\frac{m}{T} \log \left(\frac{\left(r-J_{t}\right)+J_{t} \cdot \exp \left(\frac{r \cdot \Delta t}{m}\right)}{r}\right)$

where $\Delta t$ is the time interval; $r$ is the rainfall rate; $J_{t}$ is the soil moisture at the time $t, T$ is the transmissivity, and $m$ is the parameter derived from the hydrograph recession curve which is different from that of the original TOPMODEL. The parameter $m$ can control the increase or decrease of $J_{t}$ which is estimated with the previous iteration $J_{t-1}$ :

$$
J_{t}=\frac{r}{\left[\frac{r-J_{t-1}}{J_{t-1}} \exp \left(\left(\frac{-r}{m}\right)+1\right)\right]}
$$

when $r=0$, i.e., if there is no rainfall, the flow $Q_{t}$ is estimated by:

$$
Q_{t}=\frac{m}{T} \log \left(1+\frac{J_{t} \cdot \Delta t}{m}\right)
$$

\section{Therefore:}

$$
J_{t}=\frac{J_{t-1}}{1+\left(\frac{J_{t-1} \cdot \Delta t}{m}\right)}
$$


Once the total flow is estimated, it is multiplied by the cell size to obtain the discharges from each cell. In addition, the TOPMODEL inserted into the CAESAR-Lisflood depends directly on $m$ which controls the peak and duration of the hydrograph generated by a rain event.

Zambrano et al. (2015) performed the model calibration for this basin, based on the statistical analysis with the flow data observed in 2015. Then, the present study used this calibrated model to generate hydrographs from the largest event occurred in 1982.

Here it should be noted that the study basin has geomorphological features such as high slopes, narrow stretches, and narrow plains with V-shaped valleys, and a lithology characterized widely with basaltic spills, which does not allow a significant change in topography during the period 1982-2015. Furthermore, a significant change in land-use in this basin was not observed. Therefore, it can be considered that a potential change in topography and land-use during this time interval does not affect the accuracy of mapping.

The discharge values generated in the hydrological model served as input data or boundary condition of the hydrodynamic simulations. For flow propagation, CAESAR-Lisflood uses the two-dimensional inertial model LISFLOOD-FP. To calculate the $Q$ flux in all the directions between cells, the model uses a formulation derived from the 1-D moment equation of the Saint Vennant equations. This formulation is then applied in the two horizontal directions in order to simulate the flow in two dimensions on the raster.

$$
Q=\frac{q-g \cdot h_{t} \cdot \Delta t \cdot \frac{\Delta(h+z)}{\Delta x}}{\left(1+g \cdot h_{t} \cdot \Delta t \cdot n^{2} \cdot|q| / h_{t}^{10 / 3}\right)} \Delta x
$$

where $q$ is the flow between cells in the previous iteration; $g$ is the gravitational acceleration; $n$ is the Manning coefficient; $b$ is the water depth; $z$ is the elevation; $h_{t}$ is the maximum flow depth between cells; and $\Delta x$ is the cell width.

Once the flows in the four directions of the cell are calculated, the $b$ value can be estimated from the discretization of the mass conservation equation:

$$
\frac{\Delta h^{i, j}}{\Delta t}=\frac{Q_{x}^{i-l, j}-Q_{x}^{i, j}+Q_{y}^{i, j-1}-Q_{y}^{i, j}}{\Delta x^{2}}
$$

where $i$ and $j$ are the cell coordinates; and $\Delta t$ is the appropriate time interval for the modeling, which is controlled by the Courant Freidrichs Lewy condition in order to ensure a stable simulation for most flow situations.

As a result, the CAESAR-Lisflood provides discharge, water depth and velocity at each raster pixel in both the river and the floodplain. Hence, based on these simulations data and with a GIS environment, flood maps were created for the different DEMs in the present study.

\section{Comparison on flood maps}

To assess the impact of the DEM resolution on the flow dynamics, the wetted area variation as a function of depth $(\partial \mathrm{A} / \partial \mathrm{h})$ was analyzed for different cross sections along the study reach. In addition, the absolute value of the relative error in mean velocity (REMV) calculated with the Manning friction equation was evaluated:

$$
R E M V=\left|1-\left(\frac{R_{n}}{R_{r}}\right)^{2 / 3}\right| \times 100
$$

where $\mathrm{R} n$ refers to the hydraulic radio of the cross section of the two worse maps (the session of RESULT AND DISCUSSION shows that the maps with DEM_2 and DEM_1 are worse); and $\mathrm{R} r$ refers to the hydraulic radio of the reference cross section, corresponding to the best precision map (the session of RESULT AND DISCUSSION shows that the map with DEM_3 is best among three DEMs). This criterion can quantify the discrepancy between the best map and the others.

The term $\partial \mathrm{A} / \partial \mathrm{h}$ is a geometrical variable that is constant when the channel is rectangular and varies linearly when the channel section is trapezoidal. It should be stressed that $\partial \mathrm{A} / \partial \mathrm{h}$ increases rapidly for flatter seats, which happens when the stream reaches the floodplain. This variable reflects the unsteady dynamics of flow, since its behavior is consistent with the behavior of a flood wave celerity when the banks overflow. On the other hand, the velocity error by the Manning equation represents an estimation of the velocity deviation under steady or quase-steady flow conditions.

Flood maps were compared using four quantitative indices: flood area, mean flood width, mean flow depth and F statistic which is expressed with the following equation:

$$
F=100 \frac{A_{o s}}{A_{o}+A_{s}-A_{o s}}
$$

where $A$ is the observed flood area; $A$ is the simulated flood area; and $A_{\text {or }}$ refers to the observed and simulated flood area. The value of $A_{0}$ was obtained from the GPS field survey of the event that occurred in 1982.

For this survey, interviews with local residents and collection of information such as photographs and technical reports provided by the city hall of São Vendelino were carried out. Figure 1 shows the points obtained from this survey. The value of $F=100$ means a perfect combination between the observed and simulated flood areas, and a smaller $F$ indicates a discrepancy between them (Bates \& De Roo, 2000; Horritt \& Bates, 2002; Tayefi et al., 2007).

\section{RESULTS AND DISCUSSIONS}

\section{Data preparation}

The series of mean daily rainfall over the Forromeco river basin was created and analyzed. The mean annual rainfall is approximately $1679 \mathrm{~mm}$ in the Forromeco river basin. In the largest flood event which occurred on July 28th, 1982, the accumulated daily rainfall was $137 \mathrm{~mm}$.

After the transformation of the daily rainfall into an hourly one and the calibration of the hydrological model inserted in the CAESAR-Lisflood (as described by Zambrano et al., 2015), it was determined the hyetograph for the 1982 event modifying 
the peak to $75 \%$ of the total duration. Since the model requires a warming-up time or initial condition, it was necessary to simulate a more extended period than the event, approximately one more month. Figure 3 shows the hydrologic simulation results for this event.

\section{Topographic data}

To study the effect of the geometric description on the hydrodynamic model inserted in the CAESAR-Lisflood, three DEM configurations were used for the selected stretch above-mentioned.
Figure 4 shows the three different DEM configurations. The first configuration (DEM_1) includes the primary data with 20-m contour interval (Figure 4a). In the second configuration (DEM_2), the DEM re-sampling was needed for a smaller resolution, thus generating a new DEM with a 5-m resolution (Figure 4b).

The measuring points through the field survey, which supported the third configuration (DEM_3), are presented in Figure 1. The blue points are the ones raised with the GPS of the flood area of the largest event on June 28th, 1982. In total, 10 cross sections were surveyed, and 1331 quoted points were spread over the whole flood area. Through the application of the linear interpolation between these points, the detailed bathymetry

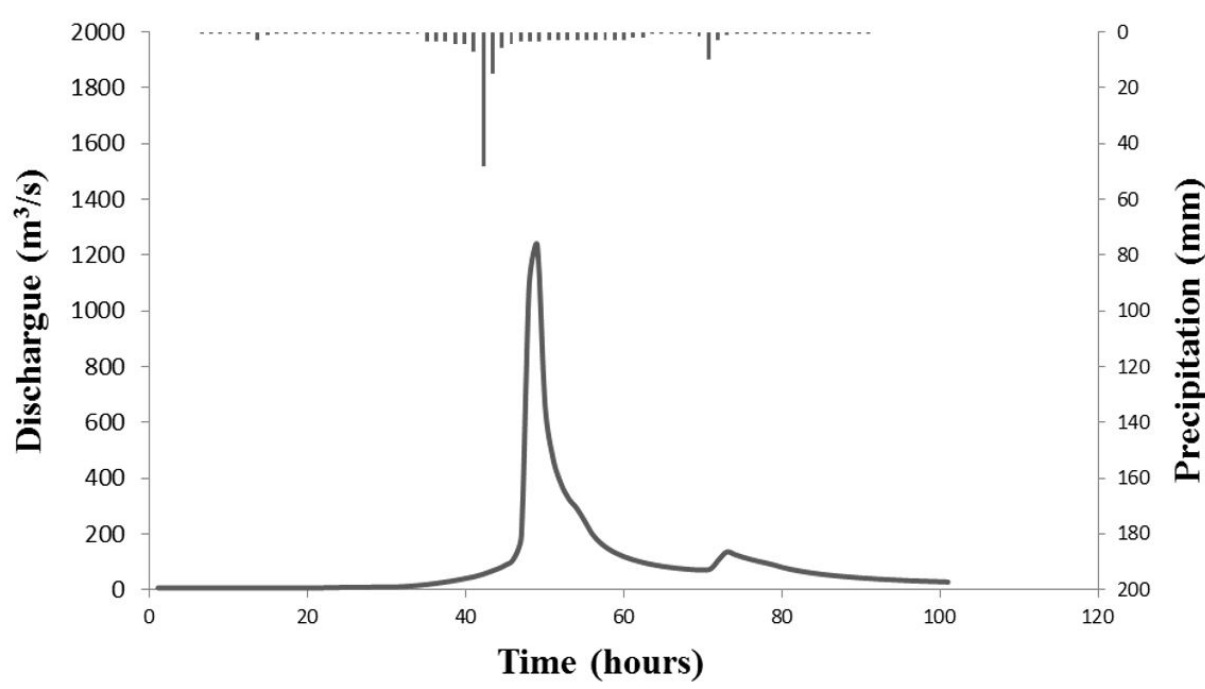

Figure 3. Hyetograph and simulated hydrograph for the 1982 event.
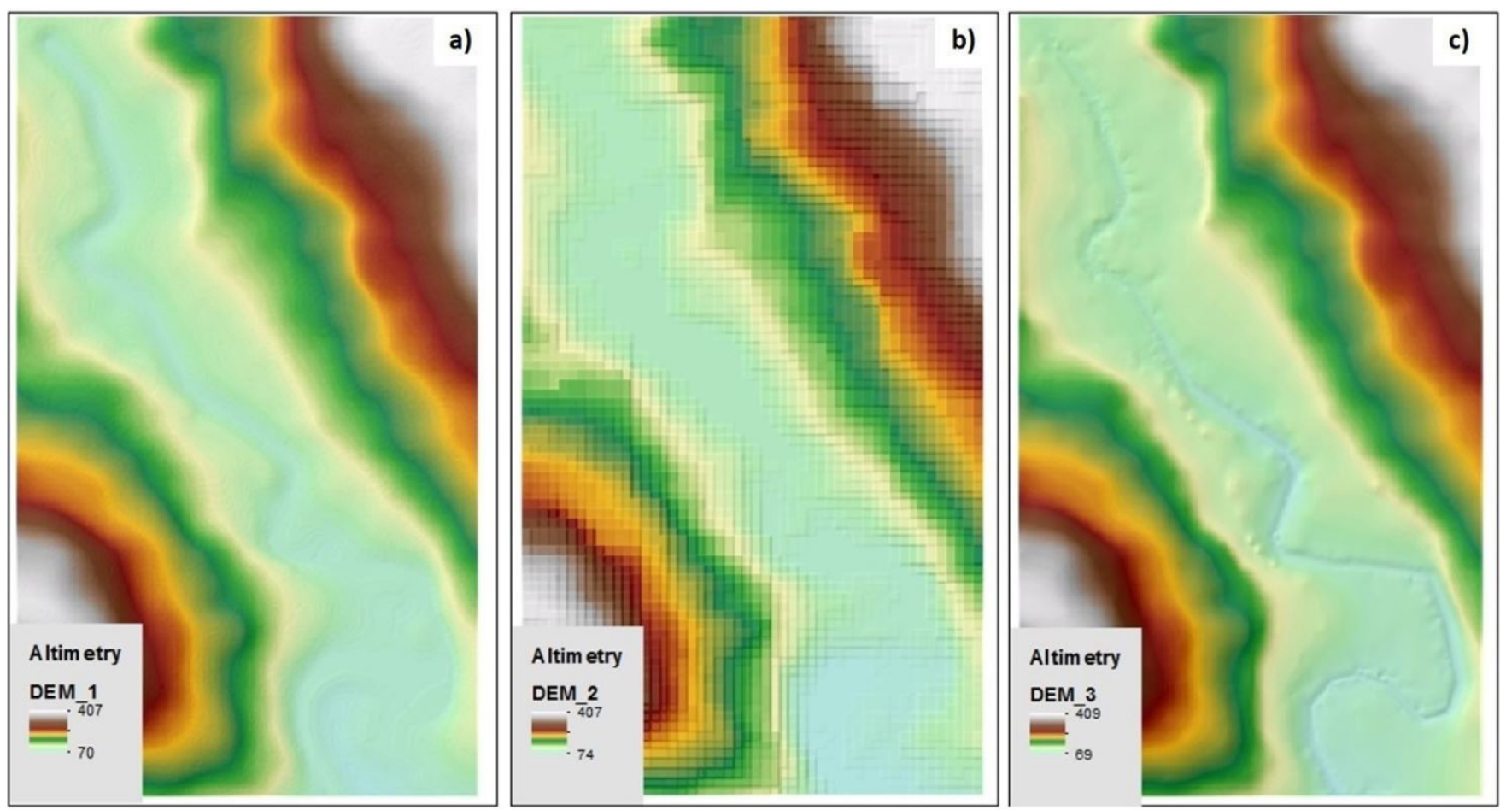

Figure 4. Digital elevation models for the different configurations: (a) DEM_1 from the 20-m contour interval; (b) DEM_2 from the re-sampling of the SRTM $30 \mathrm{~m}$; and (c) DEM_3 from field survey. 
was defined for the whole river channel to be simulated. In this way, with the quoted points, the DEM_3 was created with a 5-m resolution (Figure 4c).

Figure 5 shows the difference of elevations on four cross-sections along the selected reach. A large discrepancy can be observed among the three DEM configurations, which implies that certain DEMs cannot adequately represent both the river channel and the floodplain. According to Merwade et al. (2008a), there are several problems for generating DEMs that reliably represent the river channel: (i) the availability of detailed data for main channels, and (ii) the bathymetry data interpolation process which depends mainly on the density of measuring points, the distance between the measuring points, the measuring orientation along the flow direction, the number of measurements used in the cross-sectional creation, sections' interval, and channel morphology including width, sinuosity and sometimes presence of braided river with islands.

Figure 6a shows the effect of DEM accuracy on $\partial \mathrm{A} / \partial \mathrm{h}$ as a function of depth. It can be observed that for sections 2 and 4 the $\partial \mathrm{A} / \partial \mathrm{h}$ curves up to certain depth $(\approx 6 \mathrm{~m})$ have the similar tendency between DEM_1 and DEM_3. It indicates that the two topographic configurations represent the similar geometry of the river channel. However, once the canal overflows to the plain (Depth $>6 \mathrm{~m}$ ), the curve have a different behaviour. For downstream sections (sections 7 and 10), the DEM_1 and DEM_2 shows considerable deviations relative to the accurate DEM_3. However,
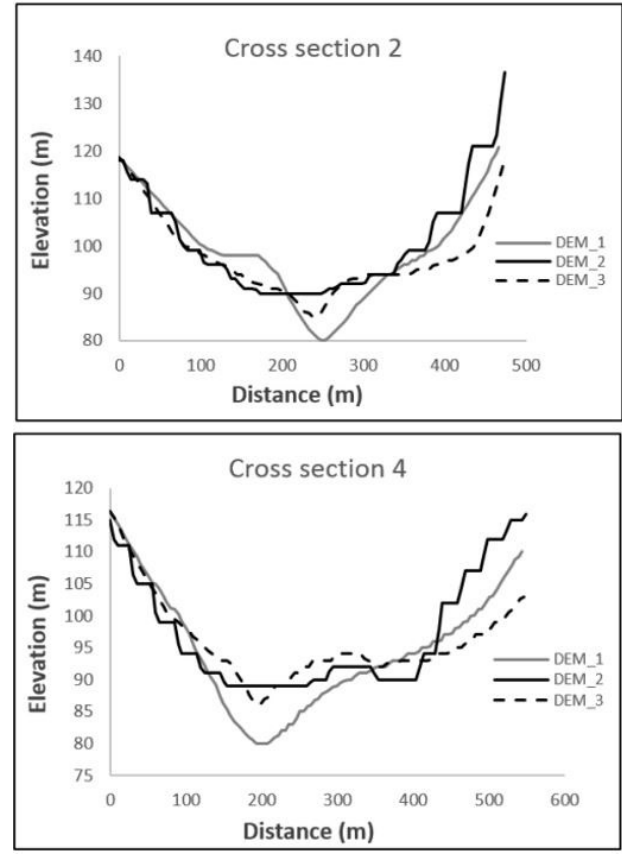
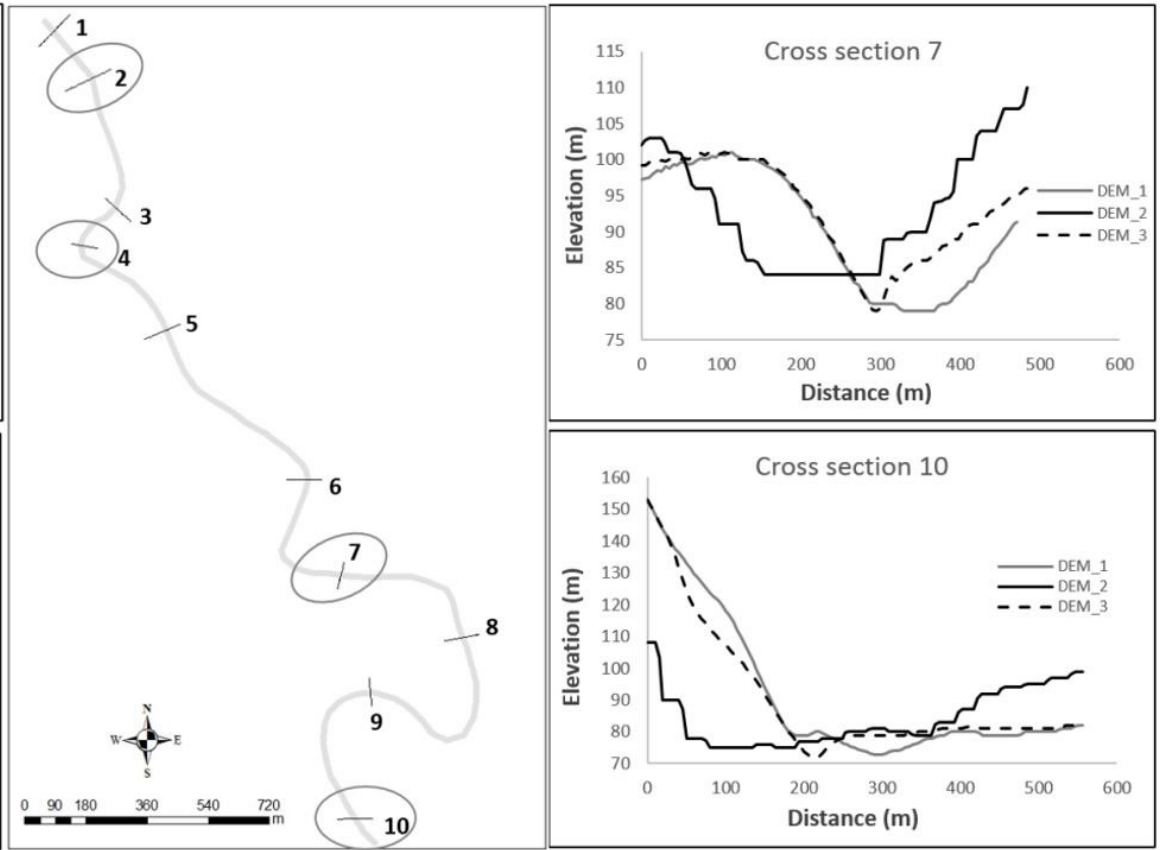

Figure 5. Comparison of cross section profile for different DEMs.
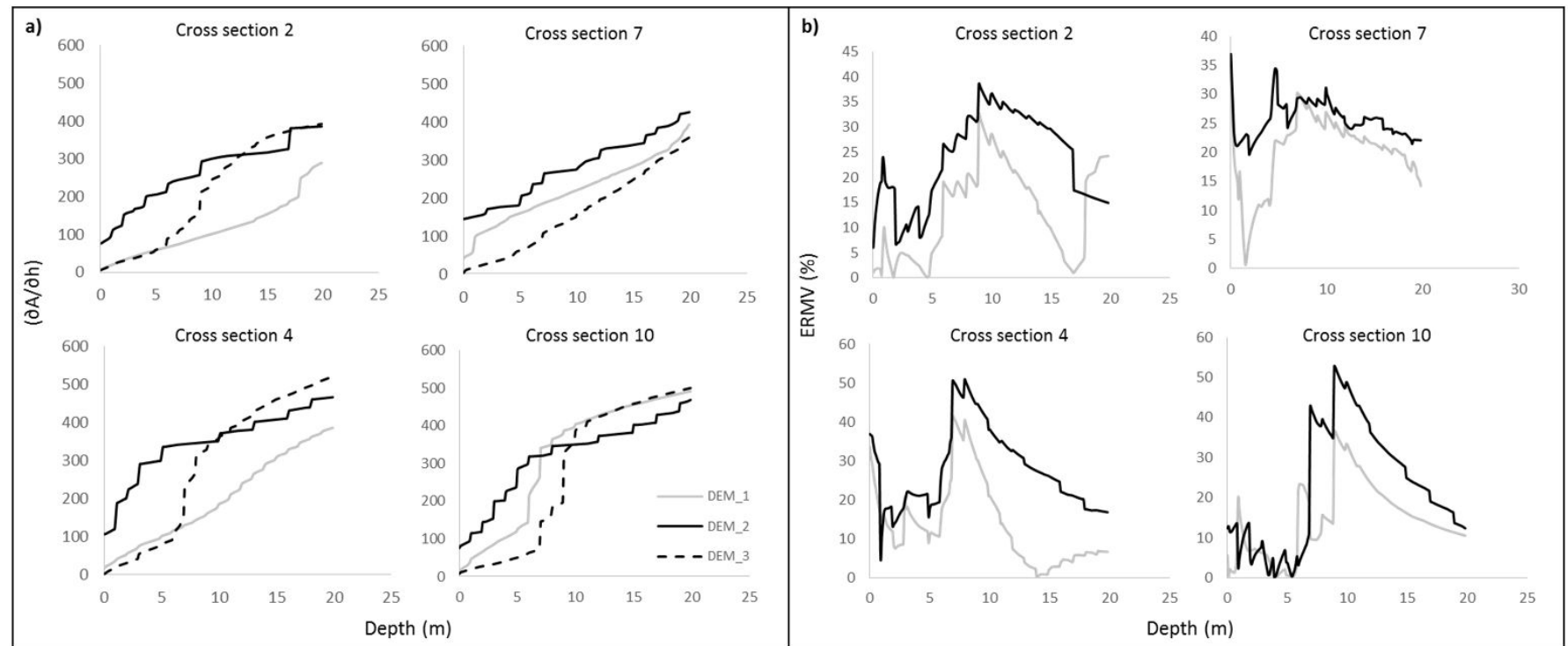

Figure 6. Comparison between different cross-sections for each set of topographic data (DEM's): (a)Wetted area variation as a function of depth; and (b) Relative error in the mean velocity calculated by the Manning friction equation. 
DEM_1 and DEM_3 have similar behaviour, especially for the larger depths at the section 10. It should be pointed out that, in case of DEM_2, the curve $\partial \mathrm{A} / \partial \mathrm{h}$ starts very far from the origin of graph. It means that this DEM represents the flat bed geometry of river channel, which is confirmed in Figure 5.

Regarding the REMV calculated for the various sections, it can be observed that DEM_2 predominantly shows the larger values at all the analyzed sections (Figure 6b). At sections 4 and 10, the largest value of REMV of with DEM_2 exceeds 50\%. However, it can be also observed that for low depths (flow inside the channel), the REMV values tend to be lower with both the DEMs.

\section{Flood areas mapping}

The application of the hydrodynamic model was performed in terms of the extent of flood area associated to the largest event which occurred in 1982. The input data were three different DEM configurations, the hydrograph elaborated for this event with the TOPMODEL simplified in the CAESAR-Lisflood (Figure 3), and some hydraulic data such as the roughness coefficient. Based on the channel characteristics presented by Chow (1959), the roughness coefficient value used in the present study was 0.04 .

Figure 7 shows the observed flood areas and also the simulated ones by the CAESAR-Lisflood with three different DEM configurations for the flood event in 1982. The effect of the DEM resolution on the flood map can be clearly observed through a visual comparison. In the study stretch, there is a tendency where the flood area decreases with the more accurate resolution. This result coincides with the result obtained by Hsu et al. (2016) which showed that the flood area increased with coarser DEMs.

The flood area and its mean width with the DEM_2 and with the DEM_1 are larger by $35 \%$ and by $20 \%$ than those with the DEM_3, respectively (Table 1). Merwade et al. (2008b) mentioned that, regardless of the topographic data accuracy, this behavior is typical for narrow stretches with V-shaped valleys when the topography representation technique is based on square cells to map the flood area. In other words, for the same number of flood cells, a coarser resolution data set tends to produce a larger flood area compared to the finer one. The reduction in the flood area with the DEM_3 might be caused by the clear existence of river channel due to the bathymetry incorporation.

In terms of the statistical analysis F, the DEM_3 had the better performance for the flood mapping than the DEM_1 and DEM_2 (Table 1). It strongly confirms that topographic data characterized mainly with the spatial resolution and precision play an important role in flood mapping. Spatial resolution is an important factor for small basins with narrow rivers. Cell sizes of $5 \mathrm{~m}$ and $20 \mathrm{~m}$ surely make a big difference for rivers that have a width of $10 \mathrm{~m}$ with flood plains of approximately $180 \mathrm{~m}$, as observed in the present study case. Therefore, the size of the cell must be at least smaller than the width of the river.

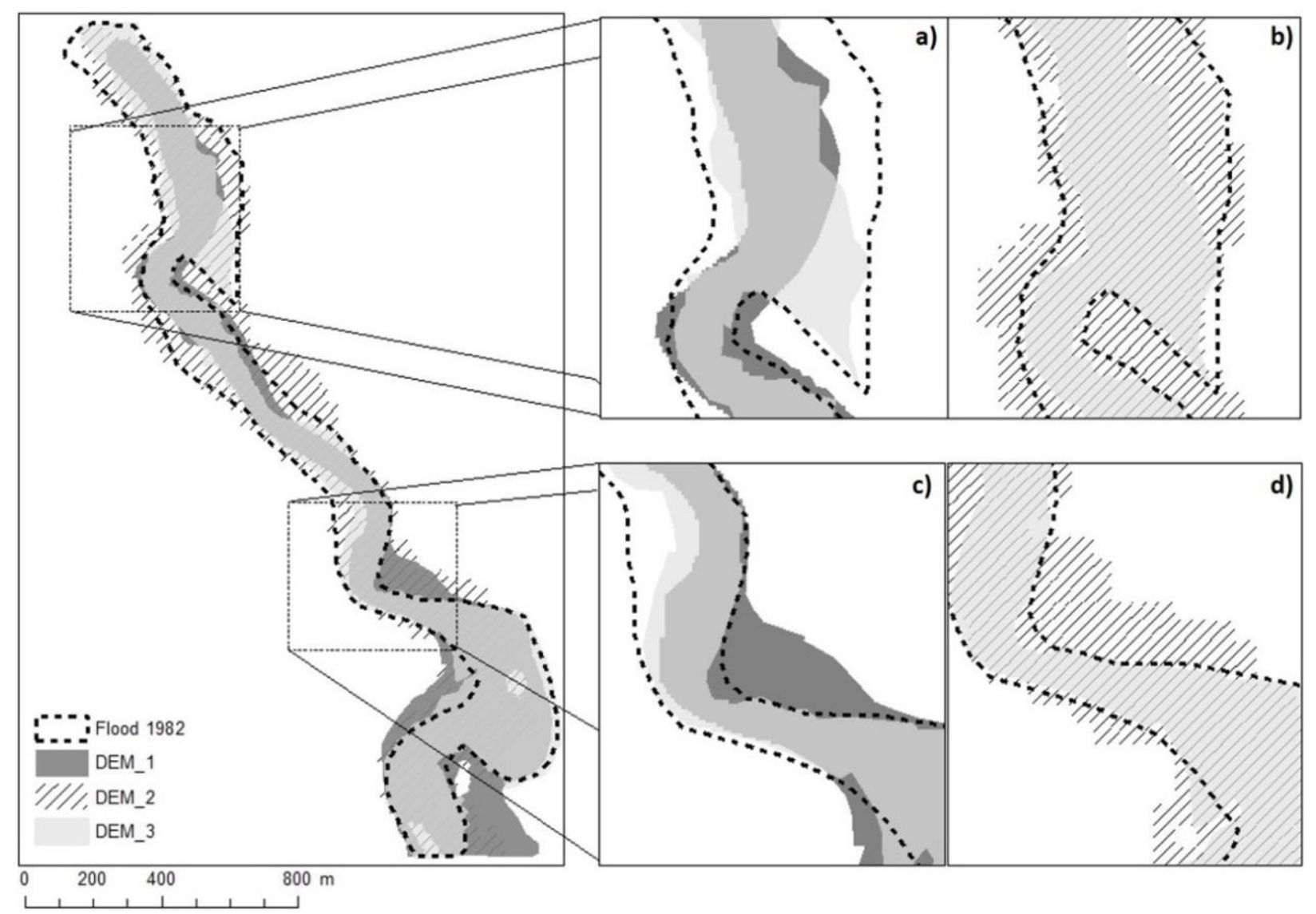

Figure 7. Observed and simulated flood areas in São Vendelino municipality in Brazil. Note that (a) and (c) compare the observed area to the simulated areas with DEM_1 and DEM_3; and (b) and (d) compare the observed area to the simulated areas with DEM_2 and DEM_3. 

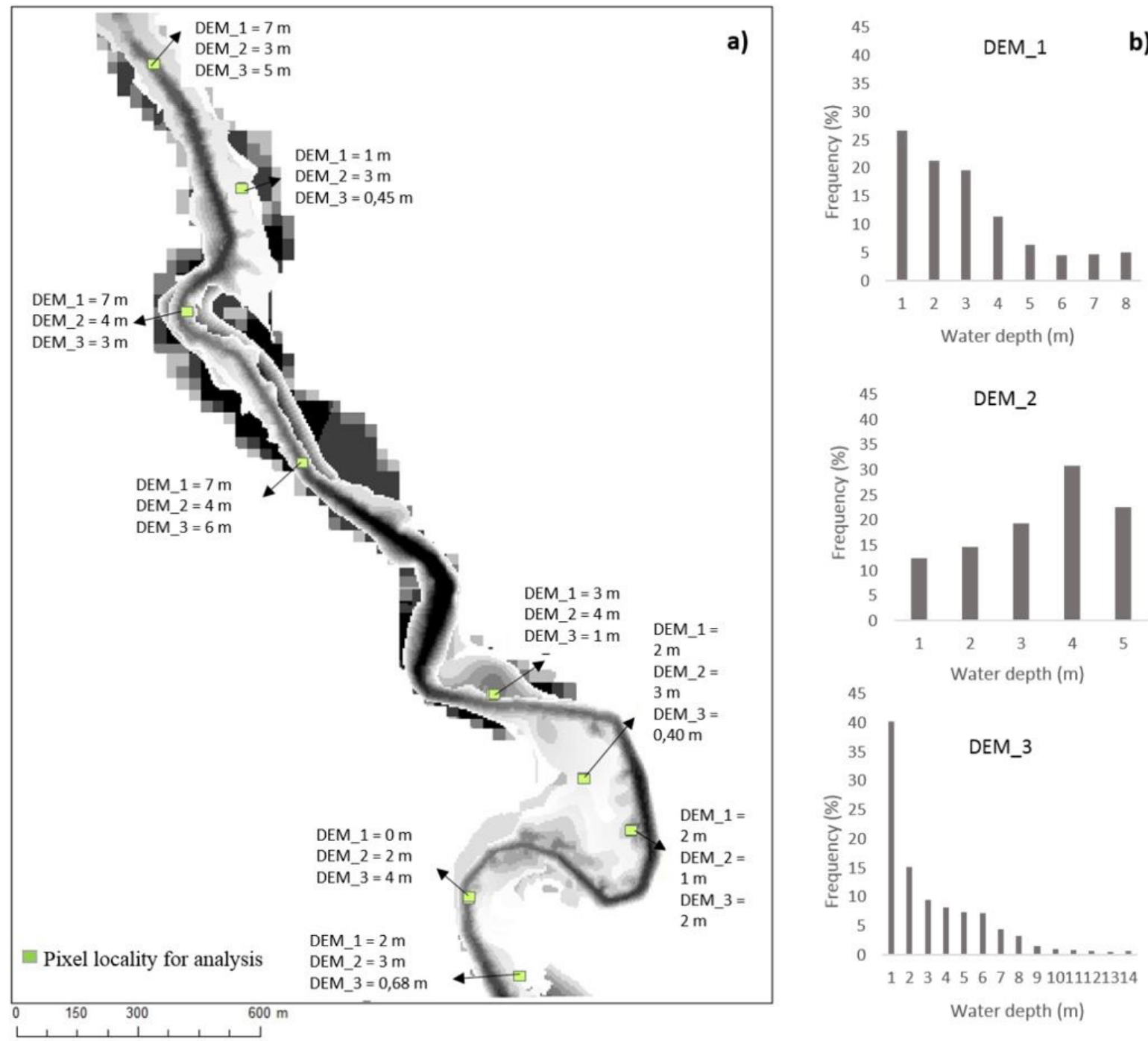

Figure 8. DEM resolution effect on the water flow depth: (a) Depth difference at various points along the stretch; and (b) frequency distribution of water depth.

On the other hand, inaccuracy in elevation data may not affect the extent of the flood area concerning the relatively steep terrain.

For a given topography and flow conditions, all the elements of the description geometry (number of cross-sections, spacing, location, and structural details - bridges and buildings) play an important role in adequate mapping of flood areas. In the present study, any structural details were not considered, which might increase uncertainty in the results. In fact, the correct representation of cross-sections at strategic locations can efficiently reduce these uncertainties and generates more reliable flood maps.

\section{Influence on water depth}

Precision in topographic data also affects the flood depth simulation with the hydrodynamic model. In general, a topographic survey with coarse resolutions produces larger extents of flood areas as mentioned above. However, the DEM effect on the water depth was not strongly confirmed with the present study. Figure 8a
Table 1. Comparison of mean flood width, flood area, and $F$ statistic.

\begin{tabular}{lccc}
\hline Map type & Mean width $(\mathbf{m})$ & Area $\left(\mathbf{k m}^{2}\right)$ & F (\%) \\
\hline Observed & - & 0.5503 & - \\
DEM_1 & 198.16 & 0.4732 & 56.34 \\
DEM_2 & 271.33 & 0.6604 & 67.64 \\
DEM_3 & 176.30 & 0.4303 & 74.11 \\
\hline
\end{tabular}

shows the depth difference among three DEM configurations at 9 locations randomly selected along the flood area, which are spatially and geomorphologically distributed. At these nine locations, there can be a tendency that coarse resolutions produced higher values of water depth.

In terms of frequency distribution of water depths (Figure 8b), the DEM_1 and DEM_3 show the similar tendency, where the larger the depth, the lower its frequency. Using the values shown in Figure $8 \mathrm{~b}$, the mean values of the water depth were calculated $2.60 \mathrm{~m}, 2.82 \mathrm{~m}$, and $2.60 \mathrm{~m}$ for the DEM_1, DEM_2 and DEM_3, respectively. 


\section{CONCLUSIONS}

The computational mapping of areas susceptible to floods is an important tool in the flood disaster management. However, this mapping is still a challenge for many scientists and managers because its procedure still contains many uncertainties related to various factors: DEM resolutions, design hydrographs, model types (1D and 2D), description of the river geometry, and so on. Although different methods of estimation for the collection of more accurate topographic data, such as LIDAR, have been proposed, there is still a strong necessity to have a good representation of the river bathymetry, which is a very sensitive factor in the flood mapping.

To evaluate the influence of sources of topographic data on flood mapping, the present study applied the CAESAR-Lisflood to the reach that crosses the urban area of São Vendelino municipality, southern Brazil, by using three different DEM configurations. Firstly, the resolution and precision of each DEM were evaluated, from the comparison of varying cross-sections along the reach, showing an important discrepancy in the elevations. Also, the DEM's were too analyzed up varying the wetted area and the REMV as a function of depth. It was observed that the variation was similar for DEM_1 and DEM_3 for some cross-sections for low depths, where the channel was being represented; however, when the flow reaches the floodplain the curve had different behaviour. Regarding REMV, the DEM_2 typically showed the most significant errors for all the analyzed sections, and for some sections, the values exceeded $50 \%$. Meanwhile, that for low depths the average REMV tends to be lower in both DEM's.

The assessment of the flood mapping was performed from the extent of the flood area, mean flood width, flow depth and the F statistics. The flood area and the mean flood width decrease as the resolution are more accurate. The difference between DEM_2 and DEM_1 is 35\% and 20\% higher than DEM_3. In terms of statistical analysis F, DEM_3 performed better with 74\% for flood mapping than DEM_1 and DEM_2. It was not clear that the DEM quality affects the flow depth. The frequency distribution of the depth, it is observed that the DEM_1 and DEM_3 behave similarly, the higher the depth of the water, the lower its frequency.

Thus, it must be emphasized that for the flood mapping with hydrodynamic modeling, topography resolution plays an important role in the representation of flooded area. Especially the detail and accurate information from bathymetry is necessary for this type of river hydrodynamic research. Therefore, institutions in charge have the task of developing appropriate methodologies so that many of these uncertainties in flood mapping are better understood and resolved.

\section{ACKNOWLEDGEMENTS}

The present study was partially supported by the Brazilian agencies CAPES-ANA (grant numbers 16/2017, Finance Code 001). The authors thank the Boeni family for all the supports for field survey over the last years. The first and the second author thank for the scholarship the Coordination for the Personnel Improvement of Higher Education (CAPES) and the Brazilian National Council for Scientific and Technological Development (CNPq), respectively.

\section{REFERENCES}

Abrams, M., Bailey, B., Tsu, H., \& Hato, M. (2010). The ASTER global DEM. Photogrammetric Engineering and Remote Sensing, 76(4), 344-348.

Agência Nacional de Águas - ANA. (2019). Retrieved in 2019, July 23, from http:/ / hidroweb.ana.gov.br/

Azizian, A. (2019). The effects of topographic map scale and costs of land surveying on geometric model and flood inundation mapping. Water Resources Management, 33, 1315-1333. http:/ /dx.doi. org/10.1007/s11269-019-2202-y.

Back, Á. J., Oliveira, J. L. R., \& Henn, A. (2012). Relações entre precipitações intensas de diferentes durações para desagregação da chuva diária em Santa Catarina. Revista Brasileira de Engenharia Agrícola e Ambiental, 16(4), 391-398. http://dx.doi.org/10.1590/ S1415-43662012000400009.

Bates, P. D., \& De Roo, A. P. J. (2000). A simple raster-based model for flood inundation simulation. Journal of Hydrology, 236(1-2), 5477. http:/ /dx.doi.org/10.1016/S0022-1694(00)00278-X.

Bates, P. D., Horritt, M. S., \& Fewtrell, T. J. (2010). A simple inertial formulation of the shallow water equations for efficient two-dimensional flood inundation modelling. Journal of Hydrology, 387(1-2), 33-45. http://dx.doi.org/10.1016/j.jhydrol.2010.03.027.

Bates, P. D., Marks, K. J., \& Horritt, M. S. (2003). Optimal use of high-resolution topographic data in flood inundation models. Hydrological Processes, 17(3), 537-557. http://dx.doi.org/10.1002/ hyp.1113.

Beven, K. J., \& Kirkby, M. J. (1979). A physically based variable contributing area model of basin hydrology. Hydrological Sciences Bulletin, 24(1), 43-69. http://dx.doi.org/10.1080/02626667909491834.

Chow, V. T. (1959). Open: channel bydraulics. New York: McGraw-Hill.

Cook, A., \& Merwade, V. (2009). Effect of topographic data, geometric configuration and modeling approach on flood inundation mapping. Journal of Hydrology, 377(1-2), 131-142. http://dx.doi. org/10.1016/j.jhydrol.2009.08.015.

Coulthard, T. J., Neal, J. C., Bates, P. D., Ramirez, J., de Almeida, G. A. M., \& Hancock, G. R. (2013). Integrating the LISFLOOD-FP 2D hydrodynamic model with the CAESAR model: implications for modelling landscape evolution. Earth Surface Processes and Landforms, 38(15), 1897-1906. http://dx.doi.org/10.1002/esp.3478.

Degiorgis, M., Gnecco, G., Gorni, S., Roth, G., Sanguineti, M., \& Taramasso, C. A. (2012). Classifiers for the detection of flood-prone areas using remote sensed elevation data. Journal of Hydrology, 470471, 302-315. http://dx.doi.org/10.1016/j.jhydrol.2012.09.006.

Farr, T., Rosen, P. A., Caro, E., Crippen, R., Duren, R., Hensley, S., Kobrick, M., Paller, M., Rodriguez, E., Roth, L., Seal, D., Shaffer, S., Shimada, J., Umland, J., Werner, M., Oskin, M., Burbank, D., \& 
Alsdorf, D. (2007). The shuttle radar topography mission. Reviews of Geophysics, 45(2), 1-33. http://dx.doi.org/10.1029/2005RG000183.

Goerl, F. R., Michel, G. P., \& Kobiyama, M. (2017). Mapeamento de áreas susceptíveis a inundação com o modelo HAND e analise do seu desempenho em diferentes resoluções espaciais. Revista Brasileira de Cartografia, 69(1), 61-69.

Grimaldi, S., Petroselli, A., Arcangeletti, E., \& Nardi, F. (2013). Flood mapping in ungauged basins using fully continuous hydrologic-hydraulic modeling. Journal of Hydrology, 487, 39-47. http://dx.doi.org/10.1016/j.jhydrol.2013.02.023.

Guha-Sapir, D., Hoyois, P., \& Below, R. (2016). Annual disaster statistical review 2016: the numbers and trends. Brussels: CRED.

Haile, A., \& Rientjes, T. (2005). Effects of LiDAR DEM resolution in flood modelling: a model sensitivity study for the city of Tegucigalpa, Honduras. In Proceedings of the ISPRS Workshop Laser Scanning 2005. The Netherlands: International Institute for GeoInformation Science and Earth Observation.

Hasenack, H., \& Weber, E. (2007). Base cartográfica digital da Serra Gaúcha: escala 1:50.000. Porto Alegre: Centro de Ecologia, Universidade Federal do Rio Grande do Sul.

Horritt, M. S., \& Bates, P. D. (2002). Evaluation of 1-D and 2-D numerical models for predicting river flood inundation. Journal of Hydrology, 268(1-4), 87-99. http://dx.doi.org/10.1016/S00221694(02)00121-X.

Horritt, M. S., Bates, P. D., \& Mattinson, M. J. (2006). Effects of mesh resolution and topographic representation in $2 \mathrm{D}$ finite volume models of shallow water fluvial flow. Journal of Hydrology, 329(1-2), 306-314. http://dx.doi.org/10.1016/j.jhydrol.2006.02.016.

Hsu, Y.-C., Prinsen, G., Bouaziz, L., Lin, Y.-J., \& Dahm, R. (2016). An investigation of DEM resolution influence on flood inundation simulation. Procedia Engineering, 154, 826-834. http:/ / dx.doi.org/10.1016/j.proeng.2016.07.435.

Hutchinson, M. F., Xu, T., \& Stein, J. A. (2011). Recent progress in the ANUDEM elevation gridding procedure. In T. Hengel, I. S. Evans, J. P. Wilson \& M. Gould (Eds.), Geomorphometry (pp. 19-22). Redlands: International Society for Geomorphometry.

Jena, P. P., Panigrahi, B., \& Chatterjee, C. (2016). Assessment of Cartosat-1 DEM for modeling floods in data scarce regions. Water Resources Management, 30(3), 1293-1309. http://dx.doi.org/10.1007/ s11269-016-1226-9.

Jung, C. H., \& Jasinski, F. M. (2015). Sensitivity of a floodplain hydrodynamic model to satellite-based DEM scale and accuracy: case study-the Atchafalaya basin. Remote Sensing, 7(6), 7938-7958. http://dx.doi.org/10.3390/rs70607938.

Jung, Y., \& Merwade, V. (2012). Uncertainty quantification in flood inundation mapping using generalized likelihood uncertainty estimate and sensitivity analysis. Journal of Hydrologic Engineering,
17(4), 507-520. http://dx.doi.org/10.1061/(ASCE)HE.19435584.0000476 .

Mai, D. T., \& De Smedt, F. (2017). A combined hydrological and hydraulic model for flood prediction in Vietnam applied to the Huong river basin as a test case study. Water, 9(11), 879. http:// dx.doi.org/10.3390/w9110879.

Merwade, V., Cook, A., \& Coonrod, J. (2008a). GIS techniques for creating river terrain models for hydrodynamic modeling and flood inundation mapping. Environmental Modelling \& Software, 23(10-11), 1300-1311. http://dx.doi.org/10.1016/j.envsoft.2008.03.005.

Merwade, V., Olivera, F., Arabi, M., \& Edleman, S. (2008b). Uncertainty in flood inundation mapping: current issues and future directions. Journal of Hydrologic Engineering, 13(7), 608-620. http://dx.doi.org/10.1061/(ASCE)1084-0699(2008)13:7(608).

Monteiro, R. L., \& Kobiyama, M. (2013). Proposta de metodologia de mapeamento de perigo de inundação. Revista de Gestão de Água da América Latina, 10(2), 25-35. http://dx.doi.org/10.21168/rega. v10n2.p13-25.

Monteiro, R. L., \& Kobiyama, M. (2014). Influencias da distribuição temporal de precipitação no mapeamento de inundação. Revista de Gestão de Água da América Latina, 11(2), 25-35. http://dx.doi. org/10.21168/rega.v11n2.p25-35.

Nobre, A. D., Cuartas, L. A., Hodnett, M., Rennó, C. D., Rodrigues, G., Silveira, A., Waterloo, M., \& Saleska, S. (2011). Height above the nearest drainage: a hydrologically relevant new terrain model. Journal of Hydrology, 404(1-2), 13-29. http://dx.doi.org/10.1016/j. jhydrol.2011.03.051.

Nobre, A. D., Cuartas, L. A., Momo, M. R., Severo, D. L., Pinheiro, A., \& Nobre, C. A. (2016). HAND contour: a new proxy predictor of inundation extent. Hydrological Processes, 30(2), 320-333. http:/ / dx.doi.org/10.1002/hyp.10581.

Paiva, R. C. D., Collischonn, W., \& Tucci, C. E. M. (2011). Large scale hydrologic and hydrodynamic modeling using limited data and a GIS based approach. Journal of Hydrology, 406(3-4), 170-181. http://dx.doi.org/10.1016/j.jhydrol.2011.06.007.

Pinho, J., Ferreira, R., Vieira, L., \& Schwanenberg, D. (2015). Comparison between two hydrodynamic models for flooding simulations at river Lima basin. Water Resources Management, 29(2), 431-444. http://dx.doi.org/10.1007/s11269-014-0878-6.

Podhorányi, M., Unucka, J., Bobál, P., \& Ríhová, V. (2013). Effects of LIDAR DEM resolution in hydrodynamic modelling: model sensitivity for cross-sections. Journal of Digital Earth, 6(1), 3-27. http://dx.doi.org/10.1080/17538947.2011.596578.

Pourali, S. H., Arrowsmith, C., Chrisman, N., Matkan, A. A., \& Mitchell, D. (2016). Topography wetness index application in flood-risk-based land use planning. Applied Spatial Analysis and Policy, 9(1), 39-54. http://dx.doi.org/10.1007/s12061-014-9130-2. 
Saksena, S., \& Merwade, V. (2015). Incorporating the effect of DEM resolution and accuracy for improved flood inundation mapping. Journal of Hydrology, 530, 180-194. http://dx.doi.org/10.1016/j. jhydrol.2015.09.069.

Shen, D., Wang, J., Cheng, X., Rui, Y., \& Ye, S. (2015). Integration of 2-D hydraulic model high-resolution lidar-derived DEM for floodplain flow modeling. Hydrology and Earth System Sciences, 19(8), 3605-3616. http://dx.doi.org/10.5194/hess-19-3605-2015.

Skinner, C. J., Coulthard, T. J., Schwanghart, W., Van de Wiel, M. J., \& Hancock, G. (2018). Global sensitivity analysis of parameter uncertainty in landscape evolution models. Geoscientific Model Development Discussion, 11(12), 4873-4888. http://dx.doi. org/10.5194/gmd-11-4873-2018.

Tayefi, V., Lane, S. N., Hardy, R. J., \& Yu, D. (2007). A comparison of one- and two-dimensional approaches to modelling flood inundation over complex upland floodplains. Hydrological Processes, 21(23), 3190-3202. http://dx.doi.org/10.1002/hyp.6523.

Teng, J., Vaze, J., Dutta, D., \& Marvanek, S. (2015). Rapid inundation modelling in large floodplains using LiDAR DEM. Water Resources Management, 29(8), 2619-2636. http://dx.doi.org/10.1007/s11269015-0960-8.

United States Army Corps of Engineers - USACE. (2010). HEC-RAS River Analysis System: bydraulic reference manual, version 4.1. Washington: U.S. Army Corps of Engineers, Hydrologic Engineering Center.

Universidade Federal de Santa Catarina - UFSC. Centro de Estudos e Pesquisas em Engenharia e Defesa Civil - CEPED. (2013). Atlas brasileiro de desastres naturais 1991 a 2012. Florianópolis: CEPED.

Universidade Federal do Rio Grande do Sul - UFRGS. (2019). Retrieved in 2019, July 23, from https://www.ufrgs.br/labgeo/ index.php/dados-espaciais/250-base-cartografica-vetorial-continuado-rio-grande-do-sul-escala-1-50-000

Vaze, J., Teng, J., \& Spencer, G. (2010). Impact of DEM accuracy and resolution on topographic indices. Environmental Modelling \& Software, 25(10), 1086-1098. http://dx.doi.org/10.1016/j. envsoft.2010.03.014.
Werner, M. G. F. (2001). Impact of grid size in GIS based flood extent mapping using a 1D flow model. Physics and Chemistry of the Earth. Part B: Hydrology, Oceans and Atmosphere, 26(7-8), 517-522. http://dx.doi.org/10.1016/S1464-1909(01)00043-0.

Wu, S., Li, J., \& Huang, G. H. (2008). A study on DEM-derived primary topographic attributes for hydrologic applications: sensitivity to elevation data resolution. Applied Geography, 28(3), 210-223. http://dx.doi.org/10.1016/j.apgeog.2008.02.006.

Yamazaki, D., Baugh, C. A., Bates, P. D., Kanae, S., Alsdorf, D. E., \& Oki, T. (2012). Adjustment of a spaceborne DEM for use in floodplain hydrodynamic modeling. Journal of Hydrology, 436-437, 81-91. http://dx.doi.org/10.1016/j.jhydrol.2012.02.045.

Yu, D., \& Lane, S. N. (2006). Urban fluvial flood modelling using a two-dimensional diffusion-wave treatment, part 1: mesh resolution effects. Hydrological Processes, 20(7), 1541-1565. http:// dx.doi.org/10.1002/hyp.5935.

Zambrano, F. C., Kobiyama, M., Michel, G. P., Monsalve, M. L. B., \& Figueiredo, M. A. (2015). Estudo preliminar do balanço hídrico da bacia do arroio Forromeco-RS com o modelo CAESARLISFLOOD. In Anais do XXI Simpósio Brasileiro de Recursos Hídricos. Brasília: ABRH.

\section{Authors contributions}

Fernando Campo Zambrano: The author performed the fieldwork, data processing, simulation test, data analysis, and was responsible for the final writing of the paper.

Masato Kobiyama: The author assisted in the fieldwork, to write the paper, and made corrections and suggestions.

Marco Alésio Figueiredo Pereira: The author assisted in the fieldwork and data processing, made corrections and suggestions.

Gean Paulo Michel: The author assisted to write the paper and made corrections and suggestions.

Fernando Mainardi Fan: The author assisted to write the paper and made corrections and suggestions. 